\title{
Stage IIIA Merkel Cell Carcinoma AJCC v7
}

National Cancer Institute

\section{Source}

National Cancer Institute. Stage IIIA Merkel Cell Carcinoma A/CC v7. NCI Thesaurus.

Code C85898.

Stage IIIA includes: Any T, N1a, M0. N1a: Micrometastasis in regional lymph nodes. M0:

No distant metastasis. (AJCC 7th Ed.) 